AT - TADBIR

JURNAL ILMIAH MANAJEMEN

Homepage: ojs.uniska.ac.id/attadbir

\title{
Pelayanan Elektronik dan Keputusan Berwisata: Studi Pada Obyek Pariwisata Edukasi Museum
}

\author{
Muhamad Guntar Suryaatmaja*, Dede Jajang Suyaman \\ Fakultas Ekonomi dan Bisnis, Universitas Singaperbangsa Karawang \\ Jl. H.S Ronggowaluyo Telukjambe Timur, Karawang, Jawa Barat 41361 \\ e-mail: guntar.surya@staff.unsika.ac.id
}

\begin{abstract}
Tourism is one of the strengths point in supporting and enforcing regional economic development. The purpose of this study was to determine the decision to visit tourists through electronic educational tourism services. This research is a quantitative research conducted using quantitative methods and data collection is carried out through observation, interviews, and recording of literature to managers and tourists at the tourist attraction of the Ranggawarsita Central Java tourism museum. The results of testing the product mix coefficient and the decision to visit show the value of $t$ count $>t$ table $(10,591>1,661)$, then Ho is rejected indicating a significant influence between the product mix and the tourist's decision to visit the Ranggawarsita Central Java Museum. Thus, the hypothesis of research on the influence of the museum product mix on the decision to visit tourists at the Ranggawarsita Museum in Central Java is answered. Managers of tourist objects require efforts to improve the accessibility and facilities contained in these attractions, so that tourists feel comfortable, considering that tourists are one of the sources of community income.
\end{abstract}

Keywords: product mix, visits decision, educational tourism, historical tourism, central java

\begin{abstract}
Abstrak
Pariwisata merupakan salah satu kekuatan dalam mempercepat dan menunjang pembangunan perekonomian daerah. Tujuan dari penelitian ini adalah untuk mengetahui keputusan berkunjung wisatawan melalui pelayanan wisata edukasi secara eletronik. Penelitian ini merupakan penelitian kuantitatif yang dilakukan dengan menggunakan metode kuantitatif dan teknik pengumpulan data dilakukan melalui observasi, wawancara, dan pencatatan literatur kepada pengelola serta wisatawan di daya tarik wisata museum Jawa Tengah ranggawarsita. Hasil pengujian koefisien bauran produk dan keputusan berkunjung menunjukan nilai $\mathrm{t}$ hitung $>\mathrm{t}$ tabel $(10.591>1,661)$ maka Ho ditolak menunjukan terdapat pengaruh yang signifikan antara bauran produk dengan keputusan wisatawan untuk mengunjungi Musuem Jawa Tengah Ranggawarsita. Dengan demikian terjawab hipotesis dari penelitian pengaruh bauran produk museum terhadap keputusan berkunjung wisatawan di museum jawa tengah ranggawarsita. Pengelola objek wisata memerlukan upaya peningkatan aksesbilitas dan fasilitas yang terdapat pada objek wisata tersebut, agar para wisatawan merasa nyaman, mengingat wisatawan merupakan salah satu sumber pendapatan masyarakat.
\end{abstract}

Kata kunci: Bauran Produk, keputusan berkunjung, wisata edukasi, wisata sejarah, jawa tengah 


\section{PENDAHULUAN}

Pariwisata internasional tahun 2020 sampai 2021 sangat berbeda sekarang, berbeda dikarenakan dunia mengalami pandemi covid 19, dan pada tahun ini sekarang kita dapat bekerja sama untuk pulih dari dari pandemi covid-19 (Lukiardianti et al 2018). Pariwisata Indonesia dimana saat ini kepariwisataan negara Indonesia tengah mengalami kemunduran selama 1 tahun, adanya kemunduran disebabkan penurunan kunjungan wisatawan mancanegara, hal ini bisa dilihat dari Gambar 1.

Dimana dari grafik di atas diketahui bahwa banyaknya turis asing yang melakukan kunjungan terhadap negara Indonesia di tahun 2018 mengalami peningkatan sebesar $12 \%$, peningkatan tersebut dikarenakan paket wisata relatif murah dan lebih bersaing serta banyaknya penerbangan langsung ke Indonesia (Rizqi, 2018). akan tetapi, pada tahun 2019 mengalami penurunan sebesar 1,9\%, penurunan tersebut disebabkan factor bencana alam dan non alam, seperti masalah

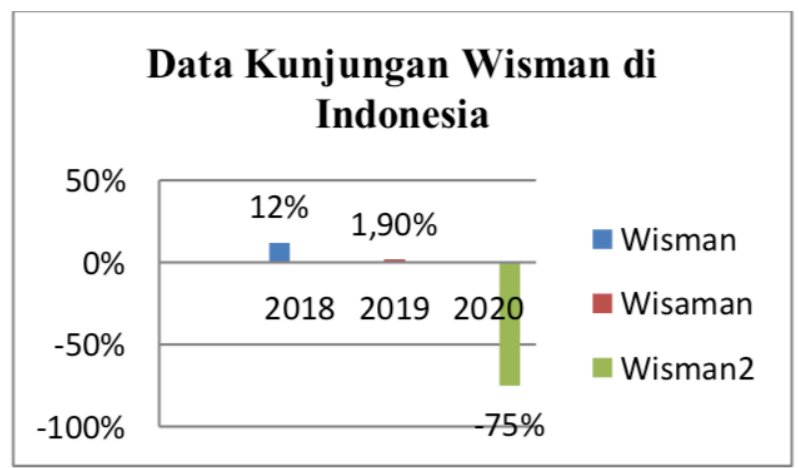

Gambar 1. Data kunjungan Wisatawan Mancanegara 2018 - 2020

Sumber: Badan Pusat Statistik, 2020

Industri pariwisata termasuk salah satu industri jasa dimana jasa menurut Valarie A. Zeithaml et al. (2018), ialah aktivitas ekonomi yang keluarannya bukan produk yang dikonsumsi bersamaan dengan waktu keamanan di beberapa daerah serta situasi politik di Indonesia bahkan menjadi fokus pasar tanah air (liputan6.com). Namun demikian pada tahun 2020 mengalami penurunan sebesar $-75 \%$ yang disebabkan wabah covid-19 yang menyebar ke belahan dunia (Badan Pusat Statistik, 2021)

Industri jasa khususnya pariwisata merupakan fondasi ekonomi yang terpukul dan menderita kerugian, akibat dari hotel serta restoran yang stop operasi, industri pariwisata tidak bisa memberikan penerimaan devisa kepada negara seperti biasanya dikarenakan adanya pandemi covid-19 (sukabumiupdate.com). Menurut Alma (2018), industri pariwisata ialah gabungan organisasi-organisasi yang secara langsung maupun tidak langsung saling berhubungan dalam membangun produk dan jasa yang diinginkan para turis luar maupun dalam pada khususnya serta traveller secara umum, selama dalam kunjungannya. Seperti travel agent, transportasi, hotel, akomodasi, serta atraksi wisata.

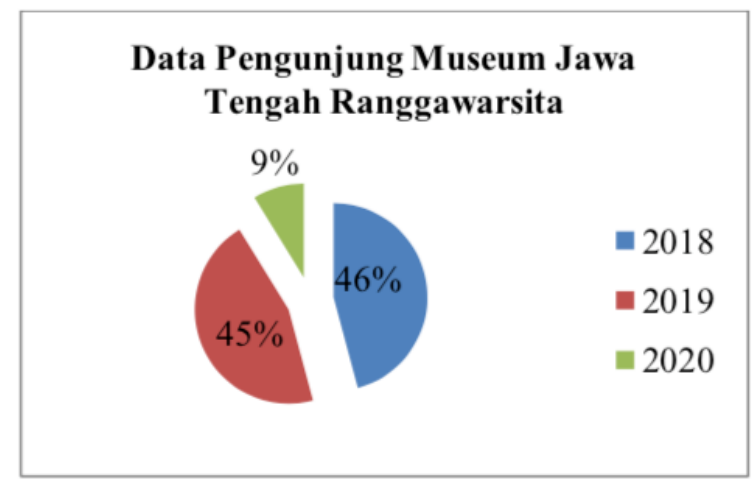

Gambar 2. Persentase Pengunjung Wuseum Ranggawarsita 2018 - 2020 Sumber: Arsip Museum Ranggawarsia, 2020

produksi serta produk yang memberikan nilai tambah seperti hiburan, waktu luang, kesehatan, dan benda tak berwujud. Sedangkan menurut Alma (2019), produk layanan adalah kinerja yang bersifat tidak 
berwujud (intangible), dikonsumsi di tempat, dan tidak dapat dimiliki oleh konsumen. Adapun e-commerce menurut Deriani, (2018) merupakan distribusi informasi mengenai pembelian dan penjualan produk oleh pelanggan melalui sistem elektronik seperti internet. Stimulus pembelian berasal dari informasi tentang produk, harga, lokasi, promosi, personel, proses, dan bukti fisik. Menurut Alma, (2018), pengambilan keputusan pembelian merupakan proses kognitif yang dipengaruhi oleh faktor-faktor seperti lingkungan, budaya, keluarga, dll. Hal tersebut akan membentuk sikap dalam diri individu kemudian melakukan pembelian. Menurut Kotler et al. (2018), ada beberapa tahap dalam proses keputusan berkunjung seperti: Indentifisikasi kebutuhan, Pencarian informasi, Evaluasi alternatif, Keputusan membeli, dan Perilaku pasca pembelian.

Menurut undang-undang republik indonesia nomor 10 tahun 2009 daya tarik wisata merupakan segala sesuatu yang mempunyai keunikan, keindahan, dan nilai berupa berbagai kekayaan alam, budaya, serta buatan yang menjadi incaran atau objek kunjungan wisatawan. Terutama objek wisata Museum Ranggawarsita Jawa Tengah .

Museum Jawa Tengah Ranggawarsita merupakan salah satu tempat wisata dengan sejarah yang panjang, sehingga banyak wisatawan yang dapat mengunjungi objek wisata ini, seperti terlihat pada Gambar 2.

Hasi dari wawancara singkat dengan pengelola, di dapat data yang ditunjukkan pada gambar 2. Dari gambar tersebut diketahui banyaknya wisatawan yang berkunjung ke objek wisata Museum Jawa Tengah Ranggawarsita pada tahun 2018 sebesar $46 \%$. Terdapat adanya peningkatan yang disebabkan oleh pihak Museum Jawa Tengah Ranggawarsita melakukan berbagai macam kegiatan belajar bersama Museum, dolan museum, diskusi permuseuman, lomba cerdas cermat, pameran tematik I, II, dan III. Sedangkan pada tahun 2019 mengalami penurunan sebesar $45 \%$, dikarenakan strategi dan kebijakan yang diarahkan oleh pengelola Museum Jawa Tengah Ranggawarsita kurang maksimal. Pada tahun 2020 mengalami penurunan sebesar $9 \%$ dikarenakan adanya pandemi covid-19.

Berdasarkan uraian di atas, penelitian ini bertujuan untuk mengetahui pengaru dari pelayanan elektronik terhadap keputusan pembelitan tiket wisata edukasi di museum Ranggawasita.

\section{KAJIAN PUSTAKA}

Pemasaran Jasa

Dimana menurut Fatihudin \& Firmansyah (2019), pemasaran jasa merupakan kegiatan dalam merencanakan, melaksanakan, memikirkan, memberi harga, mempromosikan, serta memandu ide tentang produk layanan untuk menciptakan proses komunikasi yang memenuhi tujuan pribadi dan organisasi.

Dalam memenuhi kebutuhan dan keinginan pelanggan dibutuhkan konsep pemasaran yang biasa disebut bauran pemasaran.

\section{Bauran Pemasaran}

Fachrudin \& Firmansyah (2019), bauran pemasaran merupakan kombinasi dari produk, harga, lokasi, dan promosi 4 variabel atau 7, 3 variabel berikutnya (dari konsep epmasaran yang berkembang) adalah proses, personel, dan bukti fisik.

\section{E-Commerce}

e-commerce adalah kegiatan bisnis atau jasa yang berkaitan erat dengan konsumen, produsen, penyedia layanan internet, dan 
pedagang perantara yang menyediakan layanan elektronik berbagai produk yang ditawarkan oleh organisasi layanan kepada pelanggannya (Adhiwarja, 2019). Dimensi yang tersebut terdiri dari:

1. Konten (isi situs web yang terkait dengan produk yang ditawarkan).

2. Kenyamanan (mudah).

3. layanan pelanggan (customer service)

4. Komunikasi (komunikasi pelanggan dengan penjual).

Keempat dimensi di atas sangat penting dalam memahami mengenai analisis perilaku konsumen.

Pertama tujuan bisnis jasa Museum Jawa Tengah Ranggawarsita dilakukan melalui penciptaan kepuasan pelanggan atau wisatawan dimana wisatawan merupakan fokus utama setiap bisnis.

Kedua dibutuhkannya budaya organisasi yang menggabungkan kepuasan pelanggan dengan visi dan misi perusahaan serta menggunakan pemahaman perilaku konsumen atau turis saat merancang setiap pengambilan keputusan pembelian atau berkunjung dan rencana pemasarannya.

Ketiga, salah satu fakta yang tidak bisa dsangkal adalah bahwa setiap orang adalah pelanggan, dimana perusahaan atau organisasi mempelajari cara menjadi konsumen yang bijak, agar membuat keputusan pembelian atau berkunjung yang optimal melalui sub variabel pembelian.

\section{Keputusan Pembelian atau Berkunjung}

Menurut Tjiptono, (2019) ada lima rangkaian perilaku konsumen yaitu:

1. Tentukan kebutuhan.
2. Pencarian informasi.

3. Evaluasi alternatif.

4. Pembelian dan konsumsi.

5. Evaluasi setelah pembelian.

Kelima tahap pengambilan keputusan pembelian di atas sangat penting dalam menentukan berbagai indikator dalam penelitian ini.

Penelitian yang dilakukan oleh (Putra dan Santoso, 2019) menjelaskan bahwa ecommerce merupakan alternatif bisnis yang menjanjikan, karena dapat memberikan banyak kemudahan bagi kedua belah pihak untuk melakukan transaksi perdagangan.

Sedangkan menurut (Setyoparwati, 2019) e-commerce merupakan pemasaran barang dan jasa sistem informasi melalui pemanfaatan terknologi internet. Peneliti laninya (Rakanita, 2019) ecommerce merupakan teknologi jaringan yang menggunakan database melalui email, formulir non teknis komputer lainnya, seperti sistem pengiriman barang dan peralatan bayar.

Penelitian lain yang dilakukan oleh Periyadi et al. (2020), menjelaskan bahwa pengambilan keputusan pembelian adalah memilih tindakan dua atau lebih alternatif pilihan. Isa dan Istiqomah (2020) menyatakan pengambilan keputusan pembelian ialah proses integrasi yang mengintegrasikan evaluasi dua atau lebih perilaku dan pilihan alternatif salah satu diantara mereka.

Berdasarkan uraian diatas maka konsep kerangka penelitian ditunjukan oleh gambar 2.

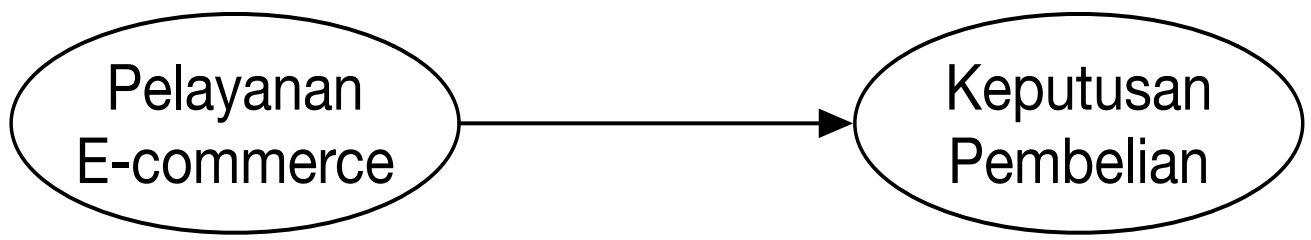

Gambar 2. Kerangka Konseptual 


\section{METODE PENELITIAN}

\section{Jenis Penelitian}

Penelitian ini bersifat kuantitatif, desain penelitiannya dengan prosedur penelitian formal yang berisi tentang definisi berdasarkan filosofi positivisme, yang digunakan untuk memeriksa populasi atau sampel tertentu, menggunakan instrumen penelitian untuk pengumpulan data, analisis data kuantitatif atau statistik yang dirancang untuk menguji hipotesis yang telah ditentukan dari sasaran penelitian dan kebutuhan tentang adanya informasi.

\section{Lokasi Penelitian}

Penelitian ini berlokasi di Museum Ranggawarsita, Semarang Jawa tengah selama satu bulan mulai pada bulan Januari hingga Februari 2021.

\section{Populasi dan Sampel}

Populasi dalam penelitian ini adalah seluruh pengunjung museum Ranggawarsita Jawa Tengah. Adapun jumlah sampel yang diambil dari penelitian ini dengan menggunakan teknik simple random sampling adalah 100 sampel.

\section{Pengembangan Instrumen}

Untuk mengukur fenomena sesuai dengan tujuan penelitian ini, alat yang digunakan adalah instrument kuesioner. Kuesioner disusun sesuai dengan menggunakan kompilasi penelitian terdahulu. Instrumen tersebut terdiri dari variabel pelayanan ecommerce (X1) sejumlah 16 item, sedangkan pengambilan keputusan berkunjung sejumlah 19 item pernyataan. Dari keseluruhan instumen tersebut di ukur menggunakan skala likert 5 skala yang dapat dilihat pada lampiran 1.

\section{Teknik Pengumpulan data}

Data pada penelitian ini dikumpulkan dengan menggunakan kuesioner secara incidental pada pintu masuk dengan kriteria bahwa sampel yang diambil telah melakukan reservasi/pencarian informasi secara daring (online)

\section{Teknik Analisis Data}

Berdasarkan tujuan dari penelitian yang telah disebutkan di awal, teknik analisis data yang digunakan dalam penelitian ini adalah regresi linear sederhana. Tahapan dari analisis regresi yang dilakukan dalam penelitian ini meliputi pengujian instrument penelitian (validitas dan reliabilitas), dilanjutkan kemudian dengan analisis inferensial melalui regresi linear sederhana.

Berdasarkan hasil perhitungan tersebut, diketahui bahwa uji hasil $0.200>$ dari 0.05 yang artinya data berdistribusi secara normal dengan yang kemudian dapat dilanjutkan untuk analisis lebih lanjut.

\section{Pengujian Instrumen}

Hasil pengujian instrument pada tabel 1 menunjukkan bahwa seluruh item yang ada pada variabel pelayanan e-commerce dan pengambilan keputusan berkunjung dapat menunjukkan kemampuan ukur yang baik berdasarkan pengujian uji korelasi dan Cronbach alpha 
Tabel 1. Hasil Uji Validitas dan Reliabilitas

\begin{tabular}{|c|c|c|c|c|c|}
\hline Variabel & Item & R-Hitung & Kesimpulan $(r>0,3)$ & Cronbach Alpha & Kesimpulan \\
\hline \multirow{16}{*}{$\begin{array}{l}\text { Pelayanan } \\
\text { E-Commerce }\end{array}$} & $\mathrm{X} 1.1$. & 0,453 & Valid & \multirow[t]{16}{*}{0,886} & \multirow[t]{16}{*}{ Reliable } \\
\hline & $\mathrm{X} 1.2$. & 0,429 & Valid & & \\
\hline & $\mathrm{X} 1.3$. & 0,575 & Valid & & \\
\hline & $\mathrm{X} 1.4$. & 0,453 & Valid & & \\
\hline & $\mathrm{X} 1.5$. & 0,494 & Valid & & \\
\hline & X1.6. & 0,455 & Valid & & \\
\hline & $\mathrm{X} 1.7$. & 0,605 & Valid & & \\
\hline & $\mathrm{X} 1.8$. & 0,501 & Valid & & \\
\hline & X1.9. & 0,438 & Valid & & \\
\hline & $\mathrm{X} 1.10$ & 0,552 & Valid & & \\
\hline & $\mathrm{X} 1.11$ & 0,568 & Valid & & \\
\hline & $\mathrm{X} 1.12$ & 0,613 & Valid & & \\
\hline & $\mathrm{X} 1.13$ & 0,613 & Valid & & \\
\hline & $\mathrm{X} 1.14$ & 0,621 & Valid & & \\
\hline & $\mathrm{X} 1.15$ & 0,624 & Valid & & \\
\hline & $\mathrm{X} 1.16$ & 0,584 & Valid & & \\
\hline \multirow{19}{*}{$\begin{array}{c}\text { Pengambilan } \\
\text { Keputusan } \\
\text { Berkunjung } \\
\text { (Y1) }\end{array}$} & Y1. & 0,617 & Valid & \multirow[t]{18}{*}{0,939} & \multirow[t]{18}{*}{ Reliable } \\
\hline & $\mathrm{Y} 2$. & 0,694 & Valid & & \\
\hline & Y3. & 0,710 & Valid & & \\
\hline & Y4. & 0,722 & Valid & & \\
\hline & Y5. & 0,578 & Valid & & \\
\hline & Y6. & 0,650 & Valid & & \\
\hline & Y7. & 0,676 & Valid & & \\
\hline & Y8. & 0,595 & Valid & & \\
\hline & Y9. & 0,653 & Valid & & \\
\hline & $\mathrm{Y} 10$ & 0,711 & Valid & & \\
\hline & $\mathrm{Y} 11$ & 0,628 & Valid & & \\
\hline & $\mathrm{Y} 12$ & 0,720 & Valid & & \\
\hline & Y13 & 0,650 & Valid & & \\
\hline & Y14 & 0,708 & Valid & & \\
\hline & Y15 & 0,727 & Valid & & \\
\hline & Y16 & 0,574 & Valid & & \\
\hline & Y17 & 0,487 & Valid & & \\
\hline & Y18 & 0,678 & Valid & & \\
\hline & Y19 & 0,533 & Valid & & \\
\hline
\end{tabular}

Sumber: Data diolah, 2021 


\section{HASIL DAN PEMBAHASAN}

\section{Hasil}

Berdasarkan hasil perhitungan di atas, maka persamaan regresi sederhana adalah $\mathrm{Y}=23.621+0.843 \mathrm{X}$, persamaan model matematis di atas menunjukan bahwa ecommerce memiliki pengaruh sebesar 0,843 terhadap keputusan berkunjung, artinya setiap peningkatan satu satuan variabel e-commerce, maka besar keputusan berkunjung adalah 23.621. Sementara $\mathrm{R}$ square adalah 0.534 artinya $53,4 \%$, cukup besar pengaruh e-commerce terhadap pengambilan keputusan wisatawan untuk mengunjungi Museum Jawa Tengah Ranggawarsita masuk kategori cukup, serta untuk melihat signifikansi koefisien determinasi dengan nilai f hitung $112.165>$ dari f tabel dengan nilai 3.939 artinya koefisien determinasi signifikan secara statistik, selain itu nilai signifikansi $0.000<$

0.05 artinya variabel e-commerce berpengaruh secara signifikan terhadap variabel keputusan berkunjung. Sedangkan nilai $\mathrm{T}$ hitung e-commerce $10.591>1.661$ yang menunjukkan adanya pengaruh secara signifikan antara e-commerce dan keputusan berkunjung.

Tabel $\mathrm{F}$ dengan nilai signifikan jauh lebih kecil dari level signifikansi kesalahan alpa $5 \%$ (0.05), oleh karena itu digunakan kombinasi produk dalam keputusan kunjungan wisatawan dengan taraf kepercayaan $95 \%$.

Tabel 1. Hasil Pengujian Normalitas

\begin{tabular}{|c|c|c|}
\hline Uji Asumsi Klasik & Hasil Uji & Kesimpulan \\
\hline Uji Normalitas & Sig. $0.200>0.05$ & Residual normal \\
\hline
\end{tabular}

Sumber: Data diolah, 2021

Tabel 2. Hasil pengujian hipotesis

\begin{tabular}{|c|c|c|c|c|c|}
\hline Variabel & Koefisien Regresi & Beta & T Hitung & Sig & Ket \\
\hline Konstanta (b0) & 23.621 & - & 5.003 & 0.000 & Signifikan \\
\hline E-Commerce (x) & 0.843 & 0.731 & 10.591 & 0.000 & Signifikan \\
\hline $\begin{array}{l}\mathrm{R} \text { square }=0.534 \\
\mathrm{R}=0.731 \\
\mathrm{~F} \text { hitung }=112.16 \\
\text { Sig. } \mathrm{F}=0.000 \\
\mathrm{~N}=100\end{array}$ & & & \multicolumn{3}{|c|}{$\begin{array}{l}\mathrm{F} \text { tabel }=3.939 \\
\mathrm{~T} \text { tabel }=1.661\end{array}$} \\
\hline
\end{tabular}

Sumber: Data diolah, 2021 


\section{Pembahasan}

Pengaruh e-commerce terhadap pengambilan keputusan pengunjung Museum Jawa Tengah Ranggawarsita pada tahun 2020 dapat dibuktikan melalui penelitian dengan hasil nilai uji t sebesar 10.591 dengan signifikan sebesar 0.000 . dengan nilai yang lebih tinggi tingkat signifikansi $\alpha=>0.05$, maka menerima $\mathrm{H} 1$ hal ini menunjukan bahwa e-commerce berpengaruh signifikan dan koefisien regresi positif sebesar 0.843 , yang berarti jika e-commerce semakin lebih baik, dengan variabel lain yang tak berubah, maka tingkat pengambilan keputusan berkunjung wisatawan yang dipengaruhi ecommerce akan meningkat sebesar 0.843 atau $84.3 \%$ di Museum Jawa Tengah Ranggawarsita pada tahun 2020. Dapat dilihat dari hasil tersebut bahwa pengaruh ecommerce memiliki nilai koefisien yang lebih besar terhadap pengambilan keputusan wisatawan yang berkunjung.

\section{KESIMPULAN DAN SARAN}

\section{Kesimpulan}

Kesimpulan $\mathrm{t}$ hitung $>\mathrm{t}$ tabel $(10.591>$ 1,661) maka Ho ditolak yang menandakan efektif secara signifikan antara e-commerce dengan pengambilan keputusan berkunjung, yang berarti e-commerce akan mempengaruhi pengambilan keputusan pengunjung Museum Jawa Tengah Rangawarsita. Meskipun hasil penelitian menunjukan hasil yang positif, namun hasil dari penelitian ini juga menunjukan bahwa strategi pemasaran yang lebih diperhatikan pengunjung harus ditentukan oleh pengelola Museum Jawa Tengah Ranggawarsita dengan membuat isi konten yang menarik, mereferensikan aplikasi gambar, dan mempermudah pengoperasian serta layanan.

Saran
Dari hasil penelitian diketahui bahwa pengaruh secara langsung e-commerce terhadap pengambilan keputusan berkunjung wisatawan memiliki tingkat efektivitas sebesar $84.3 \%$, oleh karena itu pihak pengelola museum lebih meningkatkan kreatifitas, aksesbilitas dan fasilitas, serta melakukan monitoring yang terdapat pada objek wisata, agar para wisatawan merasa nyaman untuk berkunjung ke Museum Ranggawarsita Jawa Tengah.

\section{DAFTAR PUSTAKA}

Adiwihardja, C. (2016). Ecommerce Sebagai Model Inovasi Teknologi Strategi Enterpreneur Menurut Preferensi Pengguna Pada Jakartanotebook. com. Bina Insani ICT Journal, 3(1), 154-163.

Alma, Buchari. 2018, Manajemen Pemasaran \& Pemasaran Jasa, ALFABETA, Bandung.

Badan Pusat Statistik. (2021). Perkembangan Pariwisata dan Transportasi Nasional Desember 2020. https://www.bps.go.id/pressrelease/202 1/02/01/1796/jumlah-

kunjunganwisman-ke-indonesia-bulandesember2020-mencapai-164-09-

ribukunjungan-.html (diakses pada tanggal 3 februari 2021).

Badan Pusat Statistik. (2019, February). Perkembangan Pariwisata dan Transportasi Nasional Desember 2018 (No. 12/02/Th.XXII). https://www.bps.go.id/pressrelease/201 9/02/01/1543/jumlah-kunjunganwisman-ke-indonesia-desember-2018mencapai-1-41-juta-kunjungan.html

Bisnis.com. (2020, October 24). Pandemi Covid-19 Pangkas 50 Juta Pekerjaan di Sektor Pariwisata. Tempo. 
https://bisnis.tempo.co/read/1399007/p andemi-covid-19-pangkas-50-jutapekerjaan-di-sektor-pariwisata

Deriani, N. W. (2018). Analisis Perancangan E-Commerce Sistem Penjualan Produk Hasil Olahan Kopi. Jurnal Sistem dan Informatika (JSI), 12(2), 104-111.

Fatihudin, D., \& Firmansyah, A. (2019). Pemasaran Jasa:(Strategi, Mengukur Kepuasan Dan Loyalitas Pelanggan). Deepublish.

Iman Heryanto, Totok Triwibowo, 2018, Path Analysis menggunakan SPSS dan Excel, INFORMATIKA, Bandung. Sugiyono, 2018, Metode Penelitian Kuantitatif, ALFABETA, Bandung.

Isa, M., \& Istikomah, R. (2020). Analisis Perilaku Konsumen Dalam Keputusan Pembelian Makanan di Kota Surakarta. Jurnal Manajemen Dayasaing, 21(2), 98-110.

Muhammad, K. (2020, October 24). Pandemi Covid-19 Pangkas 50 Juta Pekerjaan di Sektor Pariwisata. Sukabumi Update. https://sukabumiupdate.com/posts/raga \%20m-berita/nasional/77482-

PandemiCovid-19-Pangkas-50-Juta-

Pekerjaandi-Sektor-Pariwisata

Mutiah, D. (2019, December 6). Kunjungan Wisman ke Indonesia Menurun pada Oktober 2019, Apa Penyebabnya? liputan6.com.

https://www.liputan6.com/lifestyle/read /4127736/kunjungan-wisman-keindonesia-menurun-pada-oktober2019-apa-penyebabnya

Periyadi, P., Junaidi, J., \& Maulida, N. (2020). Pengaruh Strategi Promosi Dan Harga Terhadap Keputusan Pembelian Yang Dimediasi Oleh Minat Beli Kain Sasirangan Bordir. At-Tadbir: jurnal ilmiah manajemen, 4(2), 152-162.
Putra, T. A., \& Santoso, Y. (2019). IMPLEMENTASI E-COMMERCE SEBAGAI MEDIA PENJUALAN ONLINE PADA TOKO TATASHOPS. IDEALIS: InDonEsiA journaL Information System, 2(6), 408-414.

Rakanita, A. M. (2019). PEMANFAATAN E-COMMERCE DALAM MENINGKATKAN DAYA SAING UMKM DI DESA KARANGSARI KECAMATAN KARANGTENGAH KABUPATEN DEMAK. JURNAL EKBIS, 20(2), 1280-1289.

Setyoparwati, I. C. (2019). Pengaruh Dimensi Kepercayaan (Trust) Konsumen terhadap Kepuasan Pelanggan pada E-Commerce di Indonesia. Jurnal Ilmiah MEA (Manajemen, Ekonomi, \& Akuntansi), 3(3), 111-119.

Soenarso, S. A. (2019, July 22). Kemenpar optimis pariwisata Indonesia akan catatkan pertumbuhan di semester II2019. kontan.co.id. https://nasional.kontan.co.id/news/kem enpar-optimis-pariwisata-indonesiaakan-catatkan-pertumbuhan-disemester-ii-2019

Tjiptono, F. (2015). Strategi Pemasaran (Edisi Keempat). Yogyakarta: CV Andi Offset.

Yulianto, A. (2021, January 26). Pulihkan Pariwisata Tahun Ini, Sandi: Fokus ke 5 Destinasi. Republika Online. https://www.republika.co.id/berita/qnji g1396/pulihkan-pariwisata-tahun-inisandi-fokus-ke-5-destinasi

Y, Rizqi. (2018, April 19). Kunjungan Wisatawan ke Indonesia Terus Meningkat, Ini Penyebabnya. Phinemo.Com. https://phinemo.com/kunjunganwisatawan-ke-indonesia-terusmeningkat. 
Lampiran 1. Definisi operasional Variabel

\begin{tabular}{|c|c|c|c|}
\hline $\begin{array}{l}\text { Variabel/ } \\
\text { indikator }\end{array}$ & Indikator & Kode & Item \\
\hline \multirow{16}{*}{$\begin{array}{l}\text { E-commerce } \\
\text { (Pelayanan } \\
\text { Digital) X }\end{array}$} & \multirow{2}{*}{$\begin{array}{l}\text { Konten (isi } \\
\text { situs web yang } \\
\text { terkait dengan } \\
\text { produk yang } \\
\text { ditawarkan) } \\
\text { Museum Jawa } \\
\text { Tengah } \\
\text { Ranggawarsita }\end{array}$} & $\mathrm{X} 1.1$. & Manfaat adanya kegiatan pameran di berbagai daerah \\
\hline & & $\mathrm{X} 1.2$. & $\begin{array}{l}\text { Manfaat } \\
\text { menyaksikanbarang } \\
\text { koleksi perhiasan emas di Museum Jawa Tengah } \\
\text { Ranggawarsita }\end{array}$ \\
\hline & \multirow{6}{*}{$\begin{array}{l}\text { Kenyamanan } \\
\text { (mudah) } \\
\text { Museum Jawa } \\
\text { Tengah } \\
\text { Ranggawarsita }\end{array}$} & $\mathrm{X} 1.3$. & $\begin{array}{l}\text { Kemenarikan adanya ruang } \\
\text { apresiasi }\end{array}$ \\
\hline & & $\mathrm{X} 1.4$. & $\begin{array}{l}\text { Kemenarikan ruang audiovisual di } \\
\text { Museum Jawa Tengah Ranggawarsita }\end{array}$ \\
\hline & & $\mathrm{X} 1.5$ & $\begin{array}{l}\text { Kemenarikan adanya ruang } \\
\text { istrirahat }\end{array}$ \\
\hline & & $\mathrm{X} 1.6$. & $\begin{array}{l}\text { Kemenarikan adanya taman bermain di Museum Jawa } \\
\text { Tengah Ranggawarsita }\end{array}$ \\
\hline & & $\mathrm{X} 1.7$. & Kesesuaian lahan Parkir yang luas \\
\hline & & $\mathrm{X} 1.8$. & $\begin{array}{l}\text { Kemenarikan menggunakan audioturium untuk } \\
\text { seminar maupun rapat }\end{array}$ \\
\hline & \multirow{4}{*}{$\begin{array}{l}\text { Layanan } \\
\text { pelanggan } \\
\text { (customer } \\
\text { service) } \\
\text { Museum Jawa } \\
\text { Tengah } \\
\text { Ranggawarsita }\end{array}$} & $\mathrm{X} 1.9$. & $\begin{array}{l}\text { Kesesuaian penataan koleksi Museum Jawa } \\
\text { Tengah Ranggawarsita }\end{array}$ \\
\hline & & $\mathrm{X} 1.10$ & $\begin{array}{l}\text { Kesesuaian papan informasi yang diberikan di Museum } \\
\text { Jawa Tengah } \\
\text { Ranggawarsita. }\end{array}$ \\
\hline & & $\mathrm{X} 1.11$ & $\begin{array}{l}\text { Kemenarikan souvenir berupa buku tentang koleksi } \\
\text { Museum } \\
\text { Jawa Tengah Ranggawarsita }\end{array}$ \\
\hline & & $\mathrm{X} 1.12$ & $\begin{array}{l}\text { Kesesuaian pencahayaan koleksi Museum } \\
\text { Jawa Tengah Ranggawarsita } \\
\text { sesuai harapan }\end{array}$ \\
\hline & \multirow{4}{*}{$\begin{array}{l}\text { Communication } \\
\text { (komunikasi } \\
\text { pelanggan } \\
\text { dengan penjual) } \\
\text { Museum Jawa } \\
\text { Tengah } \\
\text { Ranggawarsita }\end{array}$} & $\mathrm{X} 1.13$ & $\begin{array}{l}\text { Pelayanan keamanan tempat } \\
\text { penyimpanan barang. }\end{array}$ \\
\hline & & $\mathrm{X} 1.14$ & $\begin{array}{l}\text { Kenyamanan AC pendingin di ruang koleksi } \\
\text { dan ruang tamu }\end{array}$ \\
\hline & & $\mathrm{X} 1.15$ & $\begin{array}{l}\text { Kebersihan } \\
\text { ruangan koleksi Museum JawaTengah } \\
\text { Ranggawarsita }\end{array}$ \\
\hline & & $\mathrm{X} 1.16$ & $\begin{array}{l}\text { Kesesuaian pelayanan informasi yang diberikan Museum } \\
\text { Jawa Tengah } \\
\text { Ranggawarsita }\end{array}$ \\
\hline
\end{tabular}




\begin{tabular}{|c|c|c|c|}
\hline $\begin{array}{l}\text { Variabel/ } \\
\text { indikator }\end{array}$ & Indikator & Kode & Item \\
\hline \multirow[t]{19}{*}{$\begin{array}{l}\text { Keputusan } \\
\text { berkunjung }\end{array}$} & \multirow{5}{*}{$\begin{array}{l}\text { Keputusan } \\
\text { Berkunjung } \\
\text { Berdasarkan } \\
\text { Pilihan Produk } \\
\text { di Museum } \\
\text { Jawa Tengah } \\
\text { Ranggawarsita }\end{array}$} & Y1. & $\begin{array}{l}\text { Kualitas pelayanan yang diberikan oleh staf Museum } \\
\text { Jawa Tengah Ranggawarsita. }\end{array}$ \\
\hline & & Y2. & $\begin{array}{l}\text { Kenyamanan pengunjung dalam menggunakan ruang } \\
\text { istrirahat }\end{array}$ \\
\hline & & Y3. & $\begin{array}{l}\text { Keamanan pengunjung dalam menggunakan perpustakaan } \\
\text { untuk } \\
\text { mengetahui sejarah }\end{array}$ \\
\hline & & Y4. & $\begin{array}{l}\text { Kenyamanan pengunjung dalam menggunakan } \\
\text { taman bermain }\end{array}$ \\
\hline & & Y5. & $\begin{array}{l}\text { Kelengkapan } \\
\text { fasilitas berupa masjid dan toilet }\end{array}$ \\
\hline & \multirow{4}{*}{\begin{tabular}{|l} 
Keputusan \\
Berkunjung \\
Berdasarkan \\
Pilihan Merek \\
di Museum \\
Jawa Tengah \\
Ranggawarsita
\end{tabular}} & Y6. & $\begin{array}{l}\text { Kemudaan pengunjung mengenali logo Museum } \\
\text { Jawa Tengah Ranggawarsita }\end{array}$ \\
\hline & & Y7. & $\begin{array}{l}\text { Pengalaman pengunjung yang diberikan oleh staf Museum } \\
\text { Jawa Tengah } \\
\text { Ranggawarsita }\end{array}$ \\
\hline & & Y8. & $\begin{array}{l}\text { Citra Museum Jawa Tengah Ranggawarsita yang } \\
\text { dipopulerkan } \\
\text { oleh pengunjung }\end{array}$ \\
\hline & & Y9. & $\begin{array}{l}\text { Kemudahan Mengingat merek Museum Jawa Tengah } \\
\text { Ranggawarsita }\end{array}$ \\
\hline & \multirow{5}{*}{$\begin{array}{l}\text { Keputusan } \\
\text { Berkunjung } \\
\text { Berdasarkan } \\
\text { Pilihan } \\
\text { Penyalur di } \\
\text { Museum Jawa } \\
\text { Tengah } \\
\text { Ranggawarsita }\end{array}$} & Y10 & $\begin{array}{l}\text { Kemudahan mengunjungi Museum Jawa Tengah } \\
\text { Ranggawarsita melalui travel }\end{array}$ \\
\hline & & Y11 & $\begin{array}{l}\text { Kenyamanan berwisata ke Museum Jawa Tengah } \\
\text { Ranggawarsita melalui } \\
\text { travel }\end{array}$ \\
\hline & & Y12 & $\begin{array}{l}\text { Keamanan berwisata ke Museum Jawa Tengah } \\
\text { Ranggawarsita melalui } \\
\text { travel }\end{array}$ \\
\hline & & Y13 & $\begin{array}{l}\text { Kemudahan lokasi yang } \\
\text { strategis }\end{array}$ \\
\hline & & Y14 & $\begin{array}{l}\text { Kemudahan transportasi yang } \\
\text { digunakan }\end{array}$ \\
\hline & \multirow{2}{*}{\begin{tabular}{|l|} 
Keputusan \\
Berkunjung \\
Berdasarkan \\
Pilihan Jumlah \\
berkunjung di \\
Museum Jawa \\
Tengah \\
Ranggawarsita \\
\end{tabular}} & Y15 & $\begin{array}{l}\text { Kesesuaian pengunjung yang berkunjung ke Museum Jawa } \\
\text { Tengah Ranggawarsita } \\
\text { sesuai dengan kebutuhannya }\end{array}$ \\
\hline & & Y16 & $\begin{array}{l}\text { Frekuensi berwisata di Museum Jawa Tengah } \\
\text { Ranggawarsita }\end{array}$ \\
\hline & \multirow{3}{*}{$\begin{array}{l}\text { Keputusan } \\
\text { Berkunjung } \\
\text { Berdasarkan } \\
\text { Pilihan waktu } \\
\text { berkunjung di } \\
\text { Museum Jawa } \\
\text { Tengah } \\
\text { Ranggawarsita }\end{array}$} & Y17 & $\begin{array}{l}\text { Berkunjung pada } \\
\text { saat weekkend } \\
\text { (sabtu-minggu) }\end{array}$ \\
\hline & & Y18 & $\begin{array}{l}\text { Berkunjung pada } \\
\text { saat libur } \\
\text { nasional }\end{array}$ \\
\hline & & Y19 & $\begin{array}{l}\text { Berkunjung pada } \\
\text { waktu-waktu khusus (misalnya merayakan ulang } \\
\text { tahun sekolah) }\end{array}$ \\
\hline
\end{tabular}

